\title{
Epidemiological survey of ticks and tick-borne pathogens in pet dogs in south-eastern China
}

\author{
Jianwei Zhang ${ }^{1}$, Qingbiao Liu ${ }^{1}$, Demou Wang ${ }^{1}$, Wanmeng Li $^{1}$, Frédéric Beugnet ${ }^{3}$, and Jinlin Zhou ${ }^{2, *}$ \\ ${ }^{1}$ Merial International Trade (Shanghai) Co. Ltd., Shanghai 200040, PR China \\ 2 Shanghai Veterinary Research Institute, Chinese Academy of Agricultural Sciences No. 518, Ziyue Road, Minhang District, \\ Shanghai 200241, PR China \\ 3 Merial SAS, 69007 Lyon, France
}

Received 10 May 2017, Accepted 4 September 2017, Published online 3 October 2017

\begin{abstract}
To understand the epidemiology of tick infestation and tick-borne diseases in pet dogs in southeastern China and to develop a reference for their prevention and treatment, we collected 1550 ticks parasitizing 562 dogs in 122 veterinary clinics from 20 cities of south-eastern China. Dogs were tested for common tick-borne pathogens; collected ticks were identified and processed for the detection of tick-borne pathogens. The use of an in vitro ELISA diagnostic kit for antibody detection ( $\mathrm{SNAP}^{\circledR} 4 \mathrm{Dx}{ }^{\circledR}$ Plus) on dog sera found the infection rates with Borrelia burgdorferi sensu lato, Ehrlichia canis, and Anaplasma spp. to be $0.4 \%, 1.3 \%$ and $2.7 \%$, respectively. By using a specific ELISA method, the infection rate with Babesia gibsoni was 3.9\%. Rhipicephalus sanguineus sensu lato, Haemaphysalis longicornis and Rhipicephalus haemaphysaloides were the major tick species identified on pet dogs. PCR tests were conducted to detect five tick-borne pathogens in 617 ticks. The infection rate was $10.2 \%$ for E. canis, $3.4 \%$ for Anaplasma platys, $2.3 \%$ for B. gibsoni, $0.3 \%$ for B. burgdorferis.l. and $0 \%$ for Babesia canis. Some ticks were co-infected with two (1.46\%) or three pathogens (0.16\%). These results indicate the infestation of pet dogs by ticks infected with tick-borne pathogens in south-eastern China, and the need for effective treatment and routine prevention of tick infestations in dogs.
\end{abstract}

Key words: Ticks, tick-borne pathogens, pet dogs, south-eastern China, epidemiological survey

Résumé - Enquête épidémiologique sur les tiques et les agents pathogènes transmissibles par les tiques chez les chiens de compagnie dans le Sud-Est de la Chine. Pour comprendre l'épidémiologie de l'infestation par les tiques et les maladies transmises par les tiques chez les chiens domestiques dans le Sud-Est de la Chine et afin de fournir une référence pour leur prévention et leur traitement, nous avons collecté 1550 tiques parasitant 562 chiens dans 122 cliniques vétérinaires de 20 villes du Sud-Est de la Chine. Les chiens ont été testés pour des agents pathogènes courants de tiques. Les tiques collectées ont été identifiées et traitées pour la détection de pathogènes transmissibles par tiques. L'utilisation d'un kit de diagnostic in vitro ELISA pour la détection d'anticorps ( $\mathrm{SNAP}^{\circledR} 4 \mathrm{Dx}{ }^{\circledR}$ Plus) sur les sérums de chiens, a mesuré le taux d'infection de Borrelia burgdorferi sensu lato, Ehrlichia canis et Anaplasma spp. à 0,4\%,1,3\% et 2,7\% respectivement. En utilisant une méthode ELISA spécifique, le taux d'infection de Babesia gibsoni était de 3,9\%. Rhipicephalus sanguineus sensu lato, Haemaphysalis longicornis et Rhipicephalus haemaphysaloides étaient les principales espèces de tiques identifiées sur les chiens de compagnie. Des tests par PCR ont été effectués pour détecter cinq agents pathogènes transmissibles par les tiques dans 617 tiques. Le taux d'infection était de 10,2\% pour E. canis, 3,4\% pour Anaplasma platys, $2,3 \%$ pour B. gibsoni, $0,3 \%$ pour B. burgdorferi s.l. et $0 \%$ pour Babesia canis. Certaines tiques étaient co-infectées avec deux $(1,46 \%)$ ou trois agents pathogènes $(0,16 \%)$. Ces résultats indiquent l'infestation des chiens de compagnie par des tiques infectées par des agents pathogènes transmissibles par les tiques dans le Sud-Est de la Chine et la nécessité d'un traitement efficace et de la prévention systématique des infestations de tiques chez les chiens.

\footnotetext{
*Corresponding author: jinlinzhou@shvri.ac.cn
} 


\section{Introduction}

The number of pet dogs is increasing in China as living standards have improved. As in many other countries, the dog has become a bonded family member. Among canine diseases, the zoonotic diseases are of significant importance in public health $[1,2]$. Ticks are one of the most common ectoparasites in dogs and are involved in the transmission of a number of major diseases in both dogs and humans [3,4]. With climate and environmental changes, as well as the appearance of new and re-emerging tick-borne diseases, ticks have been the focus of extensive attention in recent years $[5,6]$. The increase in the pet dog population and their close relationship with humans in China has created the need for research into the epidemiological status of ticks and the pathogens they transmit to pet dogs. However, there is very little reliable information on ticks and tick-borne agents in dogs in China. Dominant ticks reported in dogs in China are Rhipicephalus sanguineus, Haemaphysalis longicornis and Rhipicephalus haemaphysaloides [7,8]; the common tickborne agents found in dogs in China included Ehrlichia canis, Babesia gibsoni, and Anaplasma species [7,9,10,11]. A survey of the occurrence of Borrelia burgdorferi sensu lato, Ehrlichia canis, and Anaplasma phagocytophilum in dogs was undertaken and found the seroprevalence to be $0.17 \%, 2.17 \%$ and $0.5 \%$, respectively [10]. A serological investigation of vector-borne diseases in dogs from rural areas of China has shown the seroprevalence of $A$. phagocytophilum to be $7.7 \%$ by the SNAP 4Dx test kit, and $50 \%$ by indirect fluorescent antibody (IFA) testing [11]. A 3.47\% seroprevalence of Babesia gibsoni in pet dogs was observed in East China [7]. Recently, molecular detection has indicated mixed infections with tick-borne Anaplasma species in dogs in Henan, China [9] and Ehrlichia canis, and Babesia spp. in dogs in some cities of China [8]. Since epidemiological surveys on ticks and their transmitted diseases in dogs in China are scarce, there is a need for data that are more comprehensive in their coverage of the region. Therefore, we carried out a broader epidemiological survey covering south-eastern China that included 122 veterinary clinics to confirm and expand on the data reported to date.

\section{Materials and methods}

\section{Ethics approval}

The experimental animals in tick feeding were treated following the approved guidelines from the Animal Care and Use Committee of the Shanghai Veterinary Research Institute. Sampling procedures also complied with these guidelines.

\section{Collection and handling of serum samples}

Twenty cities in 16 provinces in south-eastern China were selected between October and November 2013. Three to five pet clinics were taken as sampling sites for each city. Five to 10 blood samples were collected from dogs at each clinic $(0.5-1 \mathrm{~mL})$. Dogs were presented for reasons unrelated to the suspicion of canine vector-borne disease. Collected serum was stored at $-30^{\circ} \mathrm{C}$ prior to testing. Each sample was registered and numbered.

\section{Collection and handling of tick samples}

Dogs were examined at presentation and a sample of ticks was collected from each dog if blood was sampled. No more than 10 ticks were collected from each dog and placed in a collection tube containing a wet cotton ball. Each sample was registered and numbered.

\section{Testing for the infection rate to tick-borne pathogens in dogs}

Testing for Ehrlichia, Anaplasma, and Borrelia infection rates

Serum samples from pet dogs were tested for antibodies by the rapid in-clinic enzyme-linked immunosorbent assay (ELISA) kit (SNAP ${ }^{\circledR} 4 \mathrm{Dx}^{\circledR}$, IDEXX Laboratories, Westbrook, Maine, USA), according to the instructions in the product package. Briefly, a $150 \mu \mathrm{L}$ serum sample was taken and placed in one reaction tube, $200 \mu \mathrm{L}$ testing reagent was added and after mixing the sample was put into the device sample well.

\section{Serological detection of Babesia gibsoni}

An enzyme-linked immunosorbent assay (ELISA) used for Babesia gibsoni was specifically developed in accordance with the established method [12]. The antigen used was recombinant B. gibsoni BgTRAP, expressed in Escherichia coli. A positive serum sample from an experimentally infected dog and negative control dog serum were sourced from the Shanghai Veterinary Research Institute, Chinese Academy of Agricultural Sciences.

\section{Identification of parasitic ticks on dogs}

In accordance with the morphology of ticks, an observation was performed microscopically to determine their developmental stage (larval, nymph, adult) and species. Ticks were identified using recognized morphological keys $[13,14]$. Larval and nymphal stages that were present were developed to the adult stage for identification through animal laboratory feeding.

\section{Testing for tick-borne pathogens}

\section{Extraction of tick DNA}

Following morphological identification, 3 to 5 ticks from each infested dog were processed for the extraction of pathogen DNA. A single tick was placed in liquid nitrogen and finely ground. A genomic DNA extraction kit was used (QIAamp DNA Mini kit, Qiagen, Hilden, Germany). A nucleic acid detector was used to assess the concentration and content of the genomic DNA. 
Table 1. Overview of the target gene, primer and PCR methods used for pathogen identification in sampled ticks.

\begin{tabular}{|c|c|c|c|c|}
\hline$\overline{\text { Pathogen }}$ & Target gene & Primer sequence $\left(5^{\prime}-3^{\prime}\right)$ & Method & Reference \\
\hline $\begin{array}{l}\text { Ehrlichia canis/ } \\
\text { Anaplasma platys }\end{array}$ & 16S rRNA gene & $\begin{array}{l}\text { Outer primer F: AGAGTTTGATCCTGGCTCAG } \\
\text { Outer primer R: TAGCACTCATCGTTTACAGC } \\
\text { Nested Primer: } \\
\text { A. platys-specific primers } \\
\text { F: AAGTCGAACGGATTTTGTC, and Primer R: } \\
\text { CTTTAACTTACCGAACC } \\
\text { E.canis- specific primers } \\
\text { F: CAATTATTTATAGCCTCTGGCTATAGGA, } \\
\text { and Primer R: GAGTTTGCCGGGACTTCTTCT }\end{array}$ & Nested PCR & {$[33]$} \\
\hline $\begin{array}{l}\text { Babesia gibsoni/ } \\
\text { Babesia canis }\end{array}$ & 18S rRNA gene & $\begin{array}{l}\text { PIRO-A: AGGGAGCCTGAGAGACGGCTACC } \\
\text { PIRO-B: TTAAATACGAATGCCCCCAAC }\end{array}$ & PCR & {$[34]$} \\
\hline $\begin{array}{l}\text { Borrelia burgdorferi } \\
\text { sensu lato }\end{array}$ & Flagellin gene & $\begin{array}{l}\text { Outer primer F: TGGTATGGGAGTTTCTGG } \\
\text { Outer primer R: TCTGTCATTGTAGCATCTTT } \\
\text { Nested primer F: CAGACAACAGAGGGAAAT } \\
\text { Nested primer R: } \\
\text { TCAAGTCTATTTTGGAAAGCACC }\end{array}$ & Nested PCR & {$[35]$} \\
\hline
\end{tabular}

Polymerase chain reaction (PCR)

PCR technology was used for the detection of pathogens in ticks, in combination with DNA sequencing for precise determination of pathogens. The target gene, primer, reaction conditions by PCR, and references for each pathogen are provided in Table 1.

\section{Statistical analysis}

Differences in the positive rates of pathogens in different tick species were tested by Chi-square, which was performed using IBM SPSS Statistics 20.0 software. A probability $p$ value $<0.05$ was considered statistically significant.

\section{Results}

\section{Sample collection}

Samples were collected in 20 large cities (Figure 1), from 16 provinces and municipalities directly under the Central Government in the Central and Eastern region of China. A total of 562 canine sera and 1550 ticks infesting dogs were collected and respectively tested or morphologically identified, while 617 tick DNA samples were prepared. The numbers of canine serum samples ranged from 6 to 57 in each city, 0 to 278 ticks were collected and 0 to 133 tick DNA samples were prepared.

\section{Dog serological tests}

The results of the 526 serological tests are presented in Table 2. Overall, there were 2 cases of Borrelia infection (infection rate $0.38 \%$ ), 7 cases of Ehrlichia infection (1.33\%), 14 cases of Anaplasma infection (2.66\%), 1 case of heartworm (Dirofilaria immitis) infection (0.19\%) and 22 cases of B. gibsoni infection (3.91\%). No co-infected samples were found. B. gibsoni infection was the most frequently detected among these tests.
Borrelia infection was only found in 2 out of the 20 city locations. Ehrlichia and Anaplasma infections were both found in 6 cities, while B. gibsoni infection was found in 12 out of 20 cities. The cities where tick-borne diseases were most frequently detected (seropositivity detected for more than two pathogens) were all located in southern cities of China including Hangzhou, Fuzhou, Guangzhou, Ximen, Shanghai, Nanning and Changsha. With the exception of Ningbo, in the 6 cities located in northern China (i.e., north of the Yangzi River), no tick-borne infections were detected.

\section{Identification of tick species}

As presented in Table 3, a total of 1550 ticks were collected from dogs during this investigation. Except for Hefei and Chengdu, where no ticks were collected, 1 to 278 ticks were collected from the remaining 18 cities. The ticks collected were of the three development stages i.e., larval, nymphal and adult ticks, where adults, nymphs and larvae counted for $65 \%, 24.5 \%$ and $10.5 \%$, respectively. All stages were identified. The species identified were Rhipicephalus haemaphysaloides (12.5\%), Haemaphysalis longicornis (18.4\%), and Rhipicephalus sanguineus $(68.2 \%)$.

\section{Detection of pathogens carried by ticks}

PCR tests were performed for 5 pathogens in 617 ticks, and sequencing was conducted to determine the pathogen species. The results are shown in Table 4. The most commonly identified infection was Ehrlichia canis (10.21\%), followed by Anaplasma platys (3.4\%), B. gibsoni $(2.27 \%)$, and Borrelia burgdorferi $(0.32 \%)$.

The pathogens detected in different ticks are shown in Table 4: B. gibsoni and A. platys were mostly found in the tick $H$. longicornis, but $E$. canis was predominantly found in R.haemaphysaloides and R. sanguineus. B. burgdorferi 


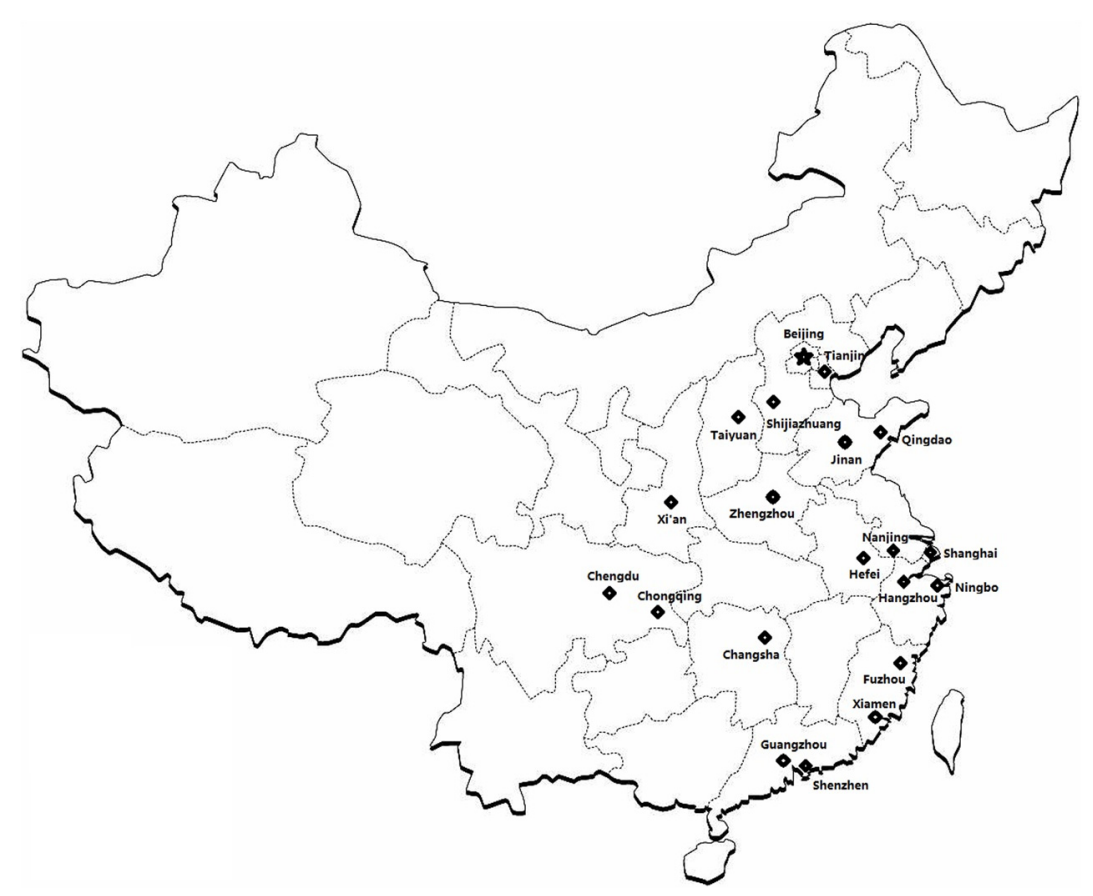

Figure 1. Location of 20 large cities in China selected for sampling.

Table 2. Serological positivity for Anaplasma spp., Borrelia spp., Ehrlichia spp. and Babesia gibsoni infection in pet dogs by ELISA.

\begin{tabular}{|c|c|c|c|c|c|}
\hline \multicolumn{2}{|c|}{ Sample } & \multirow{2}{*}{$\frac{\text { Borrelia spp. }}{\% \text { positive }}$} & \multirow{2}{*}{$\frac{\text { Ehrlichia spp. }}{\% \text { positive }}$} & \multirow{2}{*}{$\frac{\text { Anaplasma spp. }}{\% \text { positive }}$} & \multirow{2}{*}{$\frac{\text { Babesia gibsoni }}{\% \text { positive }}$} \\
\hline Origin & Number of tests & & & & \\
\hline Beijing & 30 & 0 & 0 & 0 & 0 \\
\hline Changsha & 5 & 0 & $40 \%$ & 0 & $16.67 \%$ \\
\hline Chengdu & 35 & 0 & 0 & 0 & $5.56 \%$ \\
\hline Chongqing & 12 & 0 & 0 & 0 & 0 \\
\hline Fuzhou & 40 & 0 & $2.50 \%$ & $10 \%$ & $10 \%$ \\
\hline Guangzhou & 48 & 0 & $2.08 \%$ & $2.08 \%$ & $3.64 \%$ \\
\hline Hangzhou & 35 & $2.86 \%$ & $2.86 \%$ & $5.71 \%$ & $2.86 \%$ \\
\hline Hefei & 8 & 0 & 0 & 0 & 0 \\
\hline Jinan & 10 & 0 & 0 & 0 & $10 \%$ \\
\hline Nanning & 14 & 0 & $7.14 \%$ & $7.14 \%$ & 0 \\
\hline Ningbo & 24 & 0 & 0 & 0 & 0 \\
\hline Qingdao & 12 & 0 & 0 & 0 & 0 \\
\hline Shanghai & 49 & $2.04 \%$ & $2.04 \%$ & $6.12 \%$ & $1.75 \%$ \\
\hline Shenzhen & 37 & 0 & 0 & 0 & $6.98 \%$ \\
\hline Shijiazhuang & 9 & 0 & 0 & 0 & 0 \\
\hline Taiyuan & 25 & 0 & 0 & 0 & $4 \%$ \\
\hline Tianjin & 37 & 0 & 0 & 0 & 0 \\
\hline Xiamen & 35 & 0 & 0 & $8.57 \%$ & $2.86 \%$ \\
\hline Xi'an & 33 & 0 & 0 & 0 & $8.33 \%$ \\
\hline Zhengzhou & 28 & 0 & 0 & 0 & $6.67 \%$ \\
\hline Total & 526 & $0.38 \%$ & $1.33 \%$ & $2.66 \%$ & $3.91 \%$ \\
\hline
\end{tabular}

was only found in the tick R. sanguineus. The statistical analysis indicated that B. gibsoni, A. platys, E. canis, and $B$. burgdorferi infections in the tick H. longicornis were significantly different from those in the ticks R.haemaphysaloides and R. sanguineus.

\section{Co-infection of pathogens in ticks}

Ticks co-infected with different pathogens are shown in Table 5 . One $R$. sanguineus tick was found to be coinfected with three pathogens (E.canis, A.platys, and 
Table 3. Identification of tick samples collected from dogs.

\begin{tabular}{|c|c|c|c|c|c|c|c|c|}
\hline \multirow[t]{2}{*}{ Origin } & \multirow[t]{2}{*}{ Number of ticks } & \multicolumn{3}{|c|}{ Developmental stage } & \multicolumn{4}{|c|}{ Identification of species } \\
\hline & & Larva & Nymph & Adult & $\begin{array}{l}\text { Rhipicephalus } \\
\text { haemaphysaloides }\end{array}$ & $\begin{array}{l}\text { Rhipicephalus } \\
\text { sanguineus }\end{array}$ & $\begin{array}{l}\text { Haemaphysalis } \\
\text { longicornis }\end{array}$ & $\begin{array}{l}\text { Unable to } \\
\text { identify due } \\
\text { to damage }\end{array}$ \\
\hline$\overline{\text { Beijing }}$ & 56 & 24 & 25 & 7 & & 27 & 24 & 5 \\
\hline Changsha & 71 & & & 71 & & 71 & & \\
\hline Chengdu & 0 & & & & & & & \\
\hline Chongqing & 20 & 20 & & & & & 20 & \\
\hline Fuzhou & 133 & & 32 & 101 & & 133 & & \\
\hline Guangzhou & 278 & 6 & 10 & 262 & 195 & 83 & & \\
\hline Hangzhou & 249 & & 215 & 34 & & 249 & & \\
\hline Hefei & 0 & & & & & & & \\
\hline Jinan & 17 & 9 & 7 & 1 & & & 17 & \\
\hline Nanning & 72 & 4 & 3 & 65 & & 72 & & \\
\hline Ningbo & 36 & & 4 & 32 & & 30 & 6 & \\
\hline Qingdao & 14 & & 12 & 2 & & 14 & & \\
\hline Shanghai & 13 & & 3 & 10 & & 6 & 7 & \\
\hline Shenzhen & 235 & 5 & 11 & 219 & & 231 & & 4 \\
\hline Shijiazhuang & 30 & 14 & 10 & 6 & & 1 & 29 & \\
\hline Taiyuan & 1 & & 1 & & & 1 & & \\
\hline Tianjin & 22 & & 9 & 13 & & 12 & 9 & 1 \\
\hline Xiamen & 123 & & 4 & 119 & & 123 & & \\
\hline Xi'an & 29 & 3 & 25 & 1 & & 5 & 23 & 1 \\
\hline Zhengzhou & 151 & 78 & 8 & 65 & & & 151 & \\
\hline Total & 1550 & 163 & 379 & 1008 & 195 & 1058 & 286 & 11 \\
\hline
\end{tabular}

Table 4. Pathogen detection in different ticks collected from different locations.

\begin{tabular}{|c|c|c|c|}
\hline Pathogen & $\begin{array}{l}\text { Tick species } \\
\text { (No. positive/No. samples) }\end{array}$ & Positivity & Location of positive samples (No. positive) \\
\hline$\overline{\text { Babesia canis }}$ & $\begin{array}{l}\text { R. sanguineus }(0 / 453) \\
\text { H. longicornis }(0 / 91) \\
R . \text { haemaphysaloides }(0 / 73)\end{array}$ & $\begin{array}{l}0 \\
0 \\
0\end{array}$ & \\
\hline Babesia gibsoni & $\begin{array}{l}\text { R. sanguineus }(8 / 453) \\
\text { H. longicornis }(5 / 91) \\
\text { R. haemaphysaloides }(1 / 73)\end{array}$ & $\begin{array}{l}1.77 \% \\
5.49 \% \mathrm{a} \\
1.37 \%\end{array}$ & $\begin{array}{l}\text { Fuzhou (1), Guangzhou (1), Xiamen (1), Beijing (4), } \\
\text { Taiyuan (1) } \\
\text { Beijing (2), Xi'an (3) } \\
\text { Guangzhou (1) }\end{array}$ \\
\hline Ehrlichia canis & $\begin{array}{l}R . \text { sanguineus }(50 / 453) \\
H . \text { longicornis }(3 / 91) \\
R . \text { haemaphysaloides }(10 / 73)\end{array}$ & $\begin{array}{l}11.03 \% \\
3.29 \% \mathrm{a} \\
13.69 \%\end{array}$ & $\begin{array}{l}\text { Hangzhou (9), Fuzhou (6), Guangzhou (9), Shenzhen (20), } \\
\text { Nanning (3), Qingdao (1), Ningbo (1), Changsha (1) } \\
\text { Shijiazhuang (3) } \\
\text { Guangzhou (10) }\end{array}$ \\
\hline A. Anaplasma platys & $\begin{array}{l}\text { R. sanguineus }(12 / 453) \\
\text { H. longicornis }(7 / 91) \\
\text { R. haemaphysaloides (2/73) }\end{array}$ & $\begin{array}{l}2.65 \% \\
7.69 \% \mathrm{a} \\
2.74 \%\end{array}$ & $\begin{array}{l}\text { Hangzhou (3), Guangzhou (3), Shenzhen (2), Nanning (3), } \\
\text { Qingdao (1) } \\
\text { Zhenzhou ( } 7) \\
\text { Guangzhou (2) }\end{array}$ \\
\hline Borrelia burgdorferi & $\begin{array}{l}\text { R. sanguineus }(2 / 453) \\
\text { H. longicornis }(0 / 91) \\
\text { R. haemaphysaloides }(0 / 73)\end{array}$ & $\begin{array}{l}4.4 \% \\
0 \\
0\end{array}$ & Hangzhou (2) \\
\hline
\end{tabular}

${ }^{a}$ Statistically significant $(p$ value $<0.05)$.

B. burgdorferi). Frequent co-infections with E. canis and A. platys were observed in $R$. haemaphysaloides and $R$. sanguineus. No co-infections were observed in the tick H. longicornis.

\section{Discussion}

Ticks and tick-borne diseases in owned pet dogs from 20 large Chinese cities were investigated. A large number 
Table 5. Co-infection with pathogens in ticks in this study.

\begin{tabular}{|c|c|c|c|c|}
\hline \multirow[t]{3}{*}{ Tick species } & \multicolumn{4}{|c|}{ No. (\%) of ticks infected with } \\
\hline & \multicolumn{2}{|c|}{ Two pathogens } & \multicolumn{2}{|c|}{ Three pathogens } \\
\hline & $\mathrm{Bg}+\mathrm{Ec}$ & $\mathrm{Bg}+\mathrm{Ap}$ & $\mathrm{Ec}+\mathrm{Ap}$ & $\mathrm{Ec}+\mathrm{Ap}+\mathrm{Bb}$ \\
\hline Rhipicephalus sanguineus $(\mathrm{n}=453)$ & $1(0.22 \%)$ & $1(0.22 \%)$ & $5(1.10 \%)$ & $1(0.22 \%)$ \\
\hline \multicolumn{5}{|l|}{ Haemaphysalis longicornis } \\
\hline$(\mathrm{n}=91)$ & 0 & 0 & 0 & 0 \\
\hline Rhipicephalus haemaphysaloides $(\mathrm{n}=73)$ & $1(1.37 \%)$ & 0 & $1(1.37 \%)$ & 0 \\
\hline Total $(\mathrm{n}=617)$ & $2(0.32 \%)$ & $1(0.16 \%)$ & $6(0.97 \%)$ & $1(0.16 \%)$ \\
\hline
\end{tabular}

Bg: B. gibsoni; Ec: E. canis; Ap: A. platys; Bb: B. burgdorferi.

of samples from various locations were collected. This is the first large-scale investigation of ticks and tick-borne pathogens in pet dogs and it revealed a wide distribution of ticks and pathogens, and thus the risk of vector-borne disease. Tick-borne diseases were mainly identified in southern China, which confirms that the distribution of tick-borne diseases is geographical in nature.

$B$. burgdorferi is the agent of Lyme disease, which occurs globally, and can infect a wide-range of animals including rodents, ruminants, carnivores, and birds, as well as humans. Among samples from 526 pet dogs, $0.38 \%$ were serologically positive for Borrelia infection, which correlates with investigations performed in dogs in individual reports in other countries $[15,16]$.Considering the vector's geographical distribution and abundance, it is easy to understand why the rate of positive samples reported here was significantly lower than the $4.5-11 \%$ and $1.4-11.6 \%$ infection rates reported in dogs in the UK and USA, respectively $[17,18]$. Lyme disease was first reported in China in 1985 with a seropositivity rate of $1.06 \sim 12.8 \%$ in the 30000 people randomly sampled [19]. In contrast, Borrelia infections in dogs appear to be less common than in humans, with only a single positive sample found in 300 serological samples from Beijing [10]. To the best of the authors' knowledge, no other reports utilizing serological or molecular methods present data on Borrelia infections in dogs in China. Our data indicate that the infection rate with Borrelia in pet dogs in south-eastern China is low.

The two ticks collected from pet dogs that were PCRpositive for Borrelia were identified as $R$. sanguineus and were both from Hangzhou. It is commonly considered that only Ixodes is a vector for Borrelia, but no Ixodes spp. were collected during this survey. It had been reported that $H$. longicornis and $R$. haemaphysaloides ticks could carry Borrelia in China [20], but no reports are available for $R$. sanguineus acting as a carrier. The possibility exists that R. sanguineus may have ingested Borrelia from infected dogs, but this does not necessarily qualify the tick as a vector. Only two dogs were found serologically positive for Borrelia infection; they were located in the Hangzhou and Shanghai areas which are approximately 180 kilometres apart and thus in relative geographic proximity to each other. This finding warrants further study on the prevalence of Borrelia and its tick-borne vector(s).
Ehrlichiosis and anaplasmosis are emerging tick-borne diseases in both humans and animals. E. canis and $A$. platys are the two best known pathogens that cause canine ehrlichiosis and anaplasmosis. Both agents have a worldwide distribution and were thought to be transmitted by R. sanguineus [21]. In this survey, serological tests from 526 pet dog samples demonstrated a rate of $1.33 \%$ for E. canis infection and $2.66 \%$ for Anaplasma spp. infection. Preliminary studies indicate that $A$. phagocytophilum antigens in $\mathrm{SNAP}^{\circledR} 4 \mathrm{Dx}{ }^{\circledR}$ cross-react with samples from $A$. platys-infected dogs $\left(\mathrm{SNAP}^{\circledR} 4 \mathrm{Dx}{ }^{\circledR}\right.$ kit insert 06-28502-08 IDEXX Laboratories 2017). Similar serological evaluation demonstrated a high infection rate for $E$. canis infection and for Anaplasma spp. infection in dogs in other countries $[22,16]$. The overall annual incidence of canine ehrlichiosis was estimated to be 2.1 cases per thousand dogs in France [23]. In the United States, canine ehrlichiosis is a sporadic disease [24]. A high prevalence (36\%) of active infection was recently detected in dogs infested by $R$. sanguineus in north-eastern Arizona [25]. In China, serological and PCR-based study results for Ehrlichia and Anaplasma infection have been reported concerning ticks, animals and humans $[26,27,28,29]$. This study reports the first detection of $H$. longicornis and $R$. haemaphysaloides as vectors of $E$. canis and A. platys. The three commonly identified tick species ( $R$. sanguineus, $H$. longicornis and $R$. haemaphysaloides) demonstrated a high infection rate for both E. canis, and A. platys. Based on the number of dogs sampled and their distribution, we cannot define the results as prevalences but observed infection rates. Nevertheless, the infection rates identified in this study were closely related to the serological prevalence observed in dogs in other published studies mentioned above. Particular attention should be paid to their presence due to their zoonotic potential $[2,30]$.

B. gibsoni is a virulent protozoan parasite of dogs and is one of the most important tick-borne diseases of domestic dogs. In this study, the ELISA test demonstrated an infection rate for B. gibsoni of $3.91 \%$ in pet dogs, which is similar to the seroprevalence reported in pet dogs in East China of $3.47 \%$ [7]. B. gibsoni is transmitted by ticks including $H$. longicornis [31] and $R$. sanguineus [32]. This survey also showed that $B$. gibsoni could be detected in $R$. haemaphysaloides ticks in China. Although the tick $R$. 
haemaphysaloides was found to carry B. gibsoni in this study, further studies will be necessary to clarify its actual potential as a vector of the pathogen.

The results of identification of tick species are consistent with previous studies indicating that $R$. sanguineus, H.longicornis and R. haemaphysaloides are the predominant species infesting pet dogs in China [7]. Here, larval, nymphal and adult stages were identified on pet dogs. In this study, B. canis was not detected in ticks. Ticks co-infected with multiple pathogens were found in this survey, which increases the risk of co-infections in both dogs and humans. Co-infections might result in more complex clinical manifestations and could complicate the possible diagnosis of the infecting pathogen. As yet, there are no reports of co-infections with tick-borne pathogens in humans in China; however, concerns have been raised because the pathogens might share common tick vectors and reservoir hosts, which means transmission of coinfections to humans may indeed be possible.

Owing to sampling limitations, this report provides only estimates of infection rates of important tick-borne diseases in dogs. However, the information revealed in this study confirms the correlation between ticks and the canine tick-borne diseases. Given the threat posed by ticks to dogs and the zoonotic implications of tick infestations in dogs, the critical need for effective treatment and routine prevention of tick infestations in dogs is emphasized by the findings of this study.

The authors would like to acknowledge the participating veterinary practitioners and their staff members in the 122 pet clinics in 20 cities in China, and the assistance of the Merial China Pets Team.

\section{Conflict of interest}

The work reported herein was partially funded by Merial. Several authors were employees or contractors of Merial.

\section{References}

1. Day MJ. 2011. One health: the importance of companion animal vector-borne diseases. Parasites \& Vectors, 4, 49.

2. Irwin PJ. 2014. It shouldn't happen to a $\operatorname{dog} \ldots$ or a veterinarian: clinical paradigms for canine vector-borne diseases. Trends in Parasitology, 30, 104-112.

3. Chomel B. 2011. Tick-borne infections in dogs - An emerging infectious threat. Veterinary Parasitology, 179, 294-301.

4. Dantas-Torres F, Otranto D. 2016. Best practices for preventing vector-borne diseases in dogs and humans. Trends in Parasitology, 32, 43-55.

5. Jongejan F, Uilenberg G. 2004. The global importance of ticks. Parasitology, 129, S3-S14.

6. Liu Q, He B, Huang SY, Wei F, Zhu XQ. 2014. Severe fever with thrombocytopenia syndrome, an emerging tick-borne zoonosis. Lancet Infectious Diseases, 14, 763-772.
7. Cao J, Yang Q, Zhang J, Zhou Y, Zhang H, Gong H, Zhou J. 2015. Seroprevalence survey of Babesia gibsoni infection and tick species in dogs in East China. Veterinary Parasitology, $214,12-15$.

8. Xu D, Zhang J, Shi Z, Song C, Zheng X, Zhang Y, Hao Y, Dong H, Wei L, El-Mahallawy HS, Kelly P, Xiong W, Wang H, Li J, Zhang X, Gu J, Wang C. 2015. Molecular detection of vector-borne agents in dogs from ten provinces of China. Parasites \& Vectors, 8, 501.

9. Cui Y, Yan Y, Wang X, Cao S, Zhang Y, Jian F, Zhang L, Wang R, Shi K, Ning C. 2017. First molecular evidence of mixed infections of Anaplasma species in dogs in Henan, China. Ticks and Tick Borne Diseases, 8(2), 283-289.

10. Xia Z, Yu D, Mao J, Zhang Z, Yu J. 2012. The occurrence of Dirofilaria immitis, Borrelia burgdorferi, Ehrlichia canis and Anaplasma phagocytophilum in dogs in China. Journal of Helminthology, 86(2), 185-189.

11. Wang S, He J, Zhang L. 2012. Serological investigation of vector-borne disease in dogs from rural areas of China. Asian Pacific Journal of Tropical Biomedicine, 2(2), 102-103.

12. Goo YK, Jia H, Aboge GO, Terkawi MA, Kuriki K, Nakamura C, Kumagai A, Zhou J, Lee EG, Nishikawa Y, Igarashi I, Fujisaki K, Xuan X. 2008. Babesia gibsoni: serodiagnosis of infection in dogs by an enzyme-linked immunosorbent assay with recombinant BgTRAP. Experimental Parasitology, 118, 555-560.

13. Sonenshine DE. 1993. Biology of Ticks. Oxford, USA: Oxford University Press.

14. Teng K, Jiang Z. 1991. Fasc 39 Acari: Ixodidae. In: Economic Insect Fauna of China. Beijing, China: Science Press.

15. Bell DR, Berghaus RD, Patel S, Beavers S, Fernandez I, Sanchez S. 2012. Seroprevalence of tick-borne infections in military working dogs in the Republic of Korea. Vector Borne Zoonotic Diseases, 12, 1023-1030.

16. Movilla R, García C, Siebert S, Roura X. 2016. Countrywide serological evaluation of canine prevalence for Anaplasma spp., Borrelia burgdorferi (sensu lato), Dirofilaria immitis and Ehrlichia canis in Mexico. Parasites \& Vectors, 9, 421.

17. Bowman D, Little SE, Lorentzen L, Shields J, Sullivan MP, Carlin EP. 2009. Prevalence and geographic distribution of Dirofilaria immitis, Borrelia burgdorferi, Ehrlichia canis, and Anaplasma phagocytophilum in dogs in the United States: results of a national clinic-based serologic survey. Veterinary Parasitology, 160, 138-148.

18. Shaw SE, Binns SH, Birtles RJ, Day MJ, Smithson R, Kenny MJ. 2005. Molecular evidence of tick-transmitted infections in $\operatorname{dogs}$ and cats in the United Kingdom. Veterinary Record, 157, 645-648.

19. Wu XB, Na RH, Wei SS, Zhu JS, Peng HJ. 2013. Distribution of tick-borne diseases in China. Parasites \& Vectors, 6, 119

20. Fang LQ, Liu K, Li XL, Liang S, Yang Y, Yao HW, Sun RX, Sun Y, Chen WJ, Zuo SQ. 2015. Emerging tick-borne infections in mainland China: an increasing public health threat. Lancet Infectious Diseases, 15, 1467-1479.

21. Woody BJ, Hoskins JD. 1991. Ehrlichial diseases of dogs. Veterinary Clinics of North America: Small Animal Practice, 21(1), 75-98.

22. Alho AM, Pita J, Amaro A, Amaro F, Schnyder M, Grimm F, Custódio AC, Cardoso L, Deplazes P, de Carvalho LM. 2016. Seroprevalence of vector-borne pathogens and molecular detection of Borrelia afzelii in military dogs from Portugal. Parasites \& Vectors, 9, 225. 
23. Bourdeau P. 2008. Canine vector-borne diseases in France: information obtained from veterinary clinics in national surveys. In: Proceedings of the 3rd Canine Vector-Borne Disease (CVBD) Symposium, Germany. pp. 78-84.

24. Keefe TJ, Holland CJ, Salyer PE, Ristic M. 1982. Distribution of Ehrlichia canis among military working dogs in the world and selected civilian dogs in the United States. Journal of American Veterinary Medicine Association, 181, 236-238.

25. Diniz PP, Beall MJ, Omark K, Chandrashekar R, Daniluk DA, Cyr KE, Koterski JF, Robbins RG, Lalo PG, Hegarty BC, Breitschwerdt EB. 2010. High prevalence of tickborne pathogens in dogs from an Indian reservation in northeastern Arizona. Vector Borne Zoonotic Diseases, 10, $117-123$.

26. Chen Z, Liu Q, Liu JQ, Xu BL, Lv S, Xia S, Zhou XN. 2014. Tick-borne pathogens and associated co-infections in ticks collected from domestic animals in central China. Parasites \& Vectors, 7, 1-8.

27. Li Y, Chen Z, Liu Z, Liu J, Yang J, Li Q, Li Y, Luo J, Yin H. 2015. Molecular survey of Anaplasma and Ehrlichia of red deer and sika deer in Gansu China in 2013. Transboundry and Emerging Diseases, 63(6), e228-e236.

28. Yu PF, Niu QL, Liu ZJ, Yang JF, Chen Z, Guan GQ, Liu GY, Luo JX, Yin H. 2016. Molecular epidemiological surveillance to assess emergence and re-emergence of tickborne infections in tick samples from China evaluated by nested PCRs. Acta Tropica, 158, 181-188.
29. Zhang XC, Zhang LX, Li WH, Wang SW, Sun YL, Wang YY, Guan ZZ, Liu XJ, Yang YS, Zhang SG. 2012. Ehrlichiosis and zoonotic anaplasmosis in suburban areas of Beijing, China. Vector Borne Zoonotic Diseases, 12, 932-937.

30. Sainz A, Roura X, Miró G, Estrada-Peña A, Kohn B, Harrus S, Solano-Gallego L. 2015. Guideline for veterinary practitioners on canine ehrlichiosis and anaplasmosis in Europe. Parasites \& Vectors, 8, 75.

31. Higuchi S, Fujimori M, Hoshi F, Kawamura S, Yasuda Y. 1995. Development of Babesia gibsoni in the salivary glands of the larval tick, Rhipicephalus sanguineus. Journal of Veterinary Medicine Sciences, 57, 117-119.

32. Higuchi S, Simomura S, Yoshida H, Hoshi F, Kawamura S, Yasuda Y. 1991. Development of Babesia gibsoni in the gut epithelium of the tick Haemaphysalis longicornis. Journal of Veterinary Medicine Sciences, 53, 129-131.

33. Inokuma H, Ohno K, Onishi T, Raoult D, Brouqui P. 2001. Detection of Ehrilichial infection by PCR in dogs from Yamaguchi and Okinawa prefectures, Japan. Journal of Veterinary Medicine Science, 63, 815-817.

34. Jefferies R, Ryan UM, Muhlnickel CJ, Irwin PJ. 2003. Two species of canine Babesia in Australia: Detection and characterization by PCR. Journal of Parasitology, 89, 409-412.

35. Wodecka B, Leonska A, Skotarczak B. 2010. A comparative analysis of molecular markers for the detection and identification of Borrelia spirochaetes in Ixodes ricinus. Journal of Medicine Microbiology, 59, 309-314.

Cite this article as: Zhang J, Liu Q, Wang D, Li W, Beugnet F, Zhou J. 2017. Epidemiological survey of ticks and tick-borne pathogens in pet dogs in south-eastern China. Parasite, 24, 35

- PARASTE

An international open-access, peer-reviewed, online journal publishing high quality papers on all aspects of human and animal parasitology

Reviews, articles and short notes may be submitted. Fields include, but are not limited to: general, medical and veterinary parasitology; morphology, including ultrastructure; parasite systematics, including entomology, acarology, helminthology and protistology, and molecular analyses; molecular biology and biochemistry; immunology of parasitic diseases; host-parasite relationships; ecology and life history of parasites; epidemiology; therapeutics; new diagnostic tools.

All papers in Parasite are published in English. Manuscripts should have a broad interest and must not have been published or submitted elsewhere. No limit is imposed on the length of manuscripts.

Parasite (open-access) continues Parasite (print and online editions, 1994-2012) and Annales de Parasitologie Humaine et Comparée (1923-1993) and is the official journal of the Société Française de Parasitologie. 